\title{
Reactive oxygen species and vascular biology: implications in human hypertension
}

\author{
Rhian M Touyz and Ana M Briones
}

Increased vascular production of reactive oxygen species (ROS; termed oxidative stress) has been implicated in various chronic diseases, including hypertension. Oxidative stress is both a cause and a consequence of hypertension. Although oxidative injury may not be the sole etiology, it amplifies blood pressure elevation in the presence of other pro-hypertensive factors. Oxidative stress is a multisystem phenomenon in hypertension and involves the heart, kidneys, nervous system, vessels and possibly the immune system. Compelling experimental and clinical evidence indicates the importance of the vasculature in the pathophysiology of hypertension and as such much emphasis has been placed on the (patho)biology of ROS in the vascular system. A major source for cardiovascular, renal and neural ROS is a family of non-phagocytic nicotinamide adenine dinucleotide phosphate (NADPH) oxidases (Nox), including the prototypic Nox2 homolog-based NADPH oxidase, as well as other Noxes, such as Nox1 and Nox4. Nox-derived ROS is important in regulating endothelial function and vascular tone. Oxidative stress is implicated in endothelial dysfunction, inflammation, hypertrophy, apoptosis, migration, fibrosis, angiogenesis and rarefaction, important processes involved in vascular remodeling in hypertension. Despite a plethora of data implicating oxidative stress as a causative factor in experimental hypertension, findings in human hypertension are less conclusive. This review highlights the importance of ROS in vascular biology and focuses on the potential role of oxidative stress in human hypertension.

Hypertension Research (2011) 34, 5-14; doi:10.1038/hr.2010.201; published online 28 October 2010

Keywords: antioxidant; blood pressure; inflammation; Nox; superoxide; vascular remodeling

\section{INTRODUCTION}

Hypertension is a leading cause of morbidity and mortality globally. ${ }^{1}$ The exact etiology is elusive, with only about $5 \%$ of hypertensive patients having a known cause. However, it is evident that blood pressure elevation is due to complex interactions involving multiple organ systems (heart, kidney, brain, vessels), between many genes, physiological systems (cardiovascular, renal, neural, immune) and environmental stimuli. At the molecular level, numerous factors have been implicated in the pathophysiology of hypertension including activation of the renin-angiotensin-aldosterone system, inflammation, aberrant $G$ protein-coupled receptor signaling and endothelial dysfunction. $^{2-4}$ Common to these is oxidative stress due, in large part, to excess production of vascular reactive oxygen species (ROS), to decreased nitric oxide bioavailability and to decreased antioxidant capacity. ${ }^{5}$

ROS, originally considered to cause cell damage, are now recognized to be key signaling molecules that mediate diverse biological responses such as induction of host defense genes, activation of transcription factors, phosphorylation of kinases and mobilization of ion transport systems. ${ }^{6-8}$ In the vascular system ROS has a physiological role in controlling endothelial function and vascular tone and a pathophysiological role in inflammation, hypertrophy, proliferation, apoptosis, migration, fibrosis, angiogenesis and rarefaction, important in vascular remodeling and endothelial dysfunction associated with hypertension. ${ }^{9-11}$

The relationship between free radicals and hypertension was suggested in the early $1960 s,{ }^{12}$ but it was some 40 years later that this association was investigated in greater detail when it was demonstrated that angiotensin II (Ang II)-mediated hypertension in rats increases vascular superoxide production via membrane $\mathrm{NAD}(\mathrm{P}) \mathrm{H}$ oxidase activation. ${ }^{13}$ Almost all experimental models of hypertension display some form of oxidative excess. ${ }^{14-20}$ As inhibition of ROS-generating enzymes, anti-oxidants and ROS scavengers reduce blood pressure, whereas pro-oxidants increase blood pressure, it has been suggested that ROS are causally associated with hypertension, at least in animal models.

Despite the plethora of data supporting a role for oxidative stress in experimental hypertension, the evidence in human hypertension is weak. $^{21-23}$ It is still unclear whether oxidative stress causes hypertension in humans and only a few small clinical studies showed a blood pressure-lowering effect of anti-oxidants, ${ }^{24-26}$ with most large antioxidant clinical trials failing to demonstrate any cardiovascular benefit and blood pressure lowering. ${ }^{27-29}$ Nevertheless, what is evident is that oxidative stress has a critical role in the molecular mechanisms 
associated with cardiovascular and renal injury in hypertension and that hypertension itself can contribute to oxidative stress. A greater understanding of the (patho)biology of ROS may lead to new mechanistic insights and novel diagnostics and treatments for hypertension. ROS production in vessels, as well as other organs, including the heart, kidneys and brain, likely participate in blood pressure regulation. ${ }^{30-32}$ This review will focus on ROS, the vascular system and hypertension, specifically relating to the clinical significance.

\section{VASCULAR GENERATION OF ROS}

ROS are produced as intermediates in reduction-oxidation (redox) reactions leading from $\mathrm{O}_{2}$ to $\mathrm{H}_{2} \mathrm{O} \cdot{ }^{33,34}$ The sequential univalent reduction of $\mathrm{O}_{2}$ is: $\mathrm{O}_{2} \stackrel{\mathrm{e}^{2}}{\longrightarrow} . \mathrm{O}_{2}^{-} \stackrel{\mathrm{e}^{-}}{\longrightarrow} \mathrm{H}_{2} \mathrm{O}_{2} \stackrel{\mathrm{e}-}{\longrightarrow} \mathrm{OH} \cdot \stackrel{\mathrm{e}-}{\longrightarrow} \mathrm{H}_{2} \mathrm{O}+\mathrm{O}_{2}$. Of the ROS generated in vascular cells, $\bullet \mathrm{O}_{2}^{-}$, and $\mathrm{H}_{2} \mathrm{O}_{2}$ appear to be particularly important. In biological systems, $\bullet \mathrm{O}_{2}{ }^{-}$is short-lived owing to its rapid reduction to $\mathrm{H}_{2} \mathrm{O}_{2}$ by superoxide dismutase (SOD), of which three isoforms have been characterized in mammals: copper/zinc SOD (SOD1), mitochondrial SOD (SOD2) and extracellular SOD (SOD3). ${ }^{35,36}$ The major vascular SOD is extracellular SOD. The charge on the superoxide anion makes it difficult to cross the cellular membranes, except possibly through ion channels. $\mathrm{H}_{2} \mathrm{O}_{2}$ has a longer lifespan than $\bullet \mathrm{O}_{2}{ }^{-}$, is relatively stable and is easily diffusible within and between cells. The distinct chemical properties between $\bullet \mathrm{O}_{2}{ }^{-}$and $\mathrm{H}_{2} \mathrm{O}_{2}$ and their different sites of distribution suggest that different species of ROS activate diverse signaling pathways, which lead to divergent, and potentially opposing, biological responses.

All vascular cell types produce ROS, including endothelial, smooth muscle, adventitial fibroblasts and perivascular adipocytes, and can be formed by many enzymes, including xanthine oxidoreductase, uncoupled nitric oxide synthase, mitochondrial respiratory enzymes and nicotinamide adenine dinucleotide phosphate (NADPH) oxidase $^{37-44}$ (Figure 1). Of these mitochondrial enzymes and NADPH oxidase seem to be particularly important in hypertension.

\section{Mitochondrial production of ROS}

More than $95 \%$ of $\mathrm{O}_{2}$ consumed by cells is reduced by four electrons to yield two molecules of $\mathrm{H}_{2} \mathrm{O}$ via mitochondrial electron transport chain complexes (I-IV), with $1-2 \%$ of the electron flow leaking to $\mathrm{O}_{2}$ to form $\bullet \mathrm{O}_{2}{ }^{-}$under normoxic conditions. ${ }^{45}$ Normally this $\bullet \mathrm{O}_{2}{ }^{-}$is rapidly scavenged by antioxidant enzymes, including mitochondrial manganese SOD and glutathione peroxidise. Damaged or dysfunctional mitochondria overgenerate $\bullet \mathrm{O}_{2}{ }^{-}$creating a state of redox imbalance and consequent oxidative stress. Intramitochondrial $\bullet \mathrm{O}_{2}{ }^{-}$ production triggers damaging reactions through production of $\mathrm{H}_{2} \mathrm{O}_{2}$, leading to altered adenosine triphosphate synthesis, cellular $\mathrm{Ca}^{2+}$ dysregulation and induction of mitochondrial permeability transition, all of which predispose to cell death. ${ }^{46}$ Ang II and endothelin-1 stimulate mitochondrial ROS generation in endothelial and vascular smooth muscle cells and in rat aorta in vivo. ${ }^{47-51}$ Mechanisms whereby these vasoactive agents induce such actions are unclear but could involve opening of mitochondrial potassium channels $\left(\text { mitoK }_{\text {ATP }}\right)^{52}$ and mitochondrial permeability transition. ${ }^{53}$ Ang II-induced Nox activation has also been shown to induce mitochondrial ROS formation. ${ }^{54}$

Impaired activity and/or decreased expression of mitochondrial electron transport chain complexes I, III and IV have been implicated in vascular aging and cardiovascular disease, ${ }^{55}$ and an association between mitochondrial dysfunction and blood pressure has been reported in human and experimental hypertension. ${ }^{56-58}$ Ang II-sensitive hypertension is also linked to mitochondrial-derived

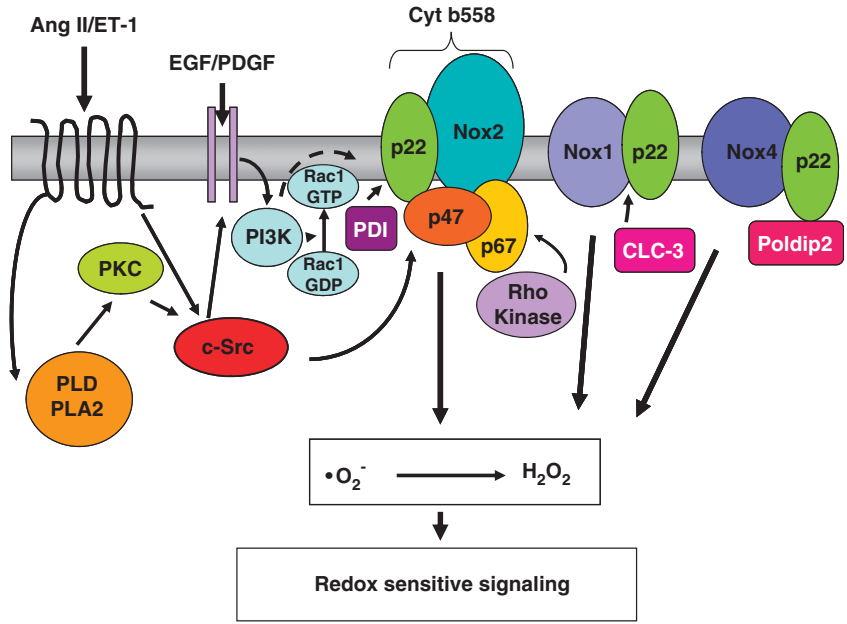

Figure 1 Regulation of Noxes in vascular cells. Activation of NADPH oxidase involves multiple subunits and many signaling pathways involving $\mathrm{c}-\mathrm{Src}$ p21 Ras, protein kinase C (PKC), phospholipase D (PLD), phospholipase $\mathrm{A}_{2} \quad\left(\mathrm{PLA} \mathrm{A}_{2}\right)$ and Rho kinase. All Noxes, except Nox5, appear to have an obligatory need for p22phox. Nox2 requires p47phox and p67phox for its activity. Oxidase activation involves Rac translocation, phosphorylation of p47phox and its translocation, possibly with p67phox, and p47phox association with cytochrome b558. Induction of Nox mRNA expression is observed in response to many stimuli including vasoactive agents (angiotensin II (Ang II), endothelin 1 (ET-1)), growth factors (epidermal growth factor (EGF), platelet-derived growth factor (PDGF)), amongst others. Recently identified Nox regulators include CIC-3, Poldip2 and protein disulfide isomerase (PDI). PDI associates with p22phox to regulate Nox2. Poldip2 associates with p22phox to activate Nox4, leading to regulation of focal adhesion turnover and vascular smooth muscle cell migration. Nox 1 is regulated by the chloride/proton exchanger CIC-3. Cyt, cytochrome; GDP, guanosine diphosphate; GTP, guanosine triphosphate; PI3K, phosphoinositide 3-kinase.

oxidative stress, as $\mathrm{AT}_{1}$ receptor blockade attenuates $\mathrm{H}_{2} \mathrm{O}_{2}$ produc$\operatorname{tion}^{59}$ and mitochondrial dysfunction in SHR, and in mice, Ang II infusion is associated with decreased expression of cardiac mitochondrial electron transport genes. ${ }^{60}$ In deoxycorticosterone acetate-salt hypertension, mitochondrial-derived ROS, via endothelin-1/endothelin A receptors, has an important role in oxidative vascular damage $^{61,62}$ In humans, mitochondrial heritability for systolic blood pressure is about $5 \%$ and mitochondrial effects may account for $35 \%$ of hypertensive pedigrees. ${ }^{63,64}$ In African Americans with hypertension-associated end-stage renal disease, mitochondrial-DNA mutations in the kidneys have been identified. ${ }^{65}$

\section{Nox family $\mathrm{NAD}(\mathrm{P}) \mathrm{H}$ oxidase-derived ROS}

$\mathrm{NAD}(\mathrm{P}) \mathrm{H}$ oxidases were originally considered as enzymes expressed only in phagocytic cells involved in host defense and innate immunity. Recent evidence indicates that there is a family of $\mathrm{NAD}(\mathrm{P}) \mathrm{H}$ oxidases, based on the discovery of gp91phox homologs. The new homologs, along with gp91phox are now designated the Nox family of $\mathrm{NAD}(\mathrm{P}) \mathrm{H}$ oxidases $^{66-68}$ and are key sources of ROS in the vasculature. The prototypical phagocytic $\mathrm{NAD}(\mathrm{P}) \mathrm{H}$ oxidase comprises five subunits: p47phox ('phox' stands for phagocyte oxidase), p67phox, p40phox, p22phox and the catalytic subunit gp91phox (also termed Nox2) ${ }^{69,70}$ In unstimulated cells p47phox, p67phox and p40phox, exist in the cytosol, whereas p22phox and gp91phox are in the membrane, where they occur as a heterodimeric flavoprotein, (cytochrome b558). On stimulation p47phox is phosphorylated and the cytosolic subunits 
form a complex that translocates to the membrane, where it associates with cytochrome b558 to assemble the active oxidase, which transfers electrons from the substrate to $\mathrm{O}_{2}$ forming $\bullet \mathrm{O}_{2}{ }^{-}{ }^{71,72}$ Activation also requires participation of Rac 2 (or Rac 1) and Rap 1A. In vascular cells, NADPH oxidase is constitutively active.

The mammalian Nox family comprises seven members, characterized primarily by the catalytic subunit that they utilize. These include Nox1, Nox2 (formerly gp91phox), Nox3, Nox4, Nox5, Duox1 and Duox $2 .^{73-75}$ All Noxes are transmembrane proteins that have conserved structural properties and that transport electrons across biological membranes to reduce $\mathrm{O}_{2}$ to $\bullet \mathrm{O}_{2}{ }^{-}$. Nox1, Nox2, Nox4 and Nox5 have been identified in vascular tissue. Characterization of Noxes as they pertain to vascular biology and hypertension has recently been reviewed. ${ }^{76,77}$ In vessels, in addition to vascular cells possessing functional Noxes, resident macrophages, neutrophils and platelets express $\mathrm{NAD}(\mathrm{P}) \mathrm{H}$ oxidase, particularly in pathological states. Accordingly these cells can also contribute to vascular oxidative stress in disease.

Nox1, found mainly in colon epithelial cells, is also expressed in other cell types, including endothelial and vascular smooth muscle cells. $^{78,79}$ Noxl requires p22phox, p47phox and p67phox for its activity. It is regulated by the redox chaperone protein disulfide isomerase in vascular smooth muscle cells ${ }^{80}$ and has been implicated in vascular smooth muscle cell migration, proliferation and extracellular matrix production, effects mediated by cofilin. ${ }^{81}$

Nox2 is the catalytic subunit of the respiratory burst oxidase in phagocytes, but is also expressed in vascular, cardiac, renal and neural cells. ${ }^{82,83}$ Human Nox2 is a highly glycosylated protein that runs with an apparent molecular mass of $\sim 70$ to $90 \mathrm{kDa}$ on SDS-polyacrylamide gel electrophoresis. Nox2 is unstable without p22phox and requires the cytosolic subunits for its full activation. In neutrophils Nox2 localizes to intracellular and plasma membranes and in vascular smooth muscle cells it also localizes with the cytoskeleton. The Nox2 gene, located on the $\mathrm{X}$ chromosome, is inducible and is highly regulated by Ang II and stretch and is upregulated in experimental hypertension. ${ }^{84-86}$

Nox4 is found in vascular cells, fibroblasts and osteoclasts and is abundantly expressed in the kidney. ${ }^{87,88}$ In vascular smooth muscle cells, Nox4 and p22phox co-localize with vinculin in focal adhesions and has been implicated in cell migration, proliferation, tube formation, angiogenesis and cell differentiation..$^{87,88}$ Nox4 has also been found in the endoplasmic reticulum, mitochondria and nucleus of vascular cells. ${ }^{89,90}$ Nox4 produces mainly $\mathrm{H}_{2} \mathrm{O}_{2}$, whereas Nox1 generates mostly $\bullet \mathrm{O}_{2}{ }^{-}$that is subsequently converted to $\mathrm{H}_{2} \mathrm{O}_{2}$. The difference in the species generated may contribute to Nox-specific actions in cell signaling. Nox4 does not seem to require p47phox, p67phox, p40phox or Rac for its activation, although Nox R1, a Nox4binding protein was recently identified, which may be important. ${ }^{91}$

Nox5 is a $\mathrm{Ca}^{2+}$-dependent homologue, found in testes and lymphoid tissue, but also in vascular cells. ${ }^{92,93}$ Although all Noxes are present in rodents and man, the mouse and rat genome does not contain the Nox 5 gene. ${ }^{94}$ Unlike other vascular Noxes, Nox 5 possesses an amino-terminal calmodulin-like domain with four binding sites for $\mathrm{Ca}^{2+}$ (EF hands) and does not require p22phox or other subunits for its activation. Nox 5 is directly regulated by intracellular $\mathrm{Ca}^{2+}$ $\left(\left(\mathrm{Ca}^{2+}\right)_{\mathrm{i}}\right)$, the binding of which induces a conformational change leading to enhanced ROS generation. ${ }^{95}$ The functional significance of vascular Nox5 is unknown, although it has been implicated in endothelial cell proliferation, angiogenesis and migration, in platelet-derived growth factor-induced proliferation of vascular smooth muscle cells and in oxidative damage in atherosclerosis. ${ }^{96,97}$ Vascular
Nox 5 is activated by thrombin, platelet-derived growth factor, Ang II and endothelin-1. ${ }^{93,98}$

\section{VASCULAR NOX DISTRIBUTION AND REGULATION Nox distribution}

Endothelial cells, vascular smooth muscle cells and adventitial fibroblasts possess multiple Nox isoforms. ${ }^{73,74}$ In pathological conditions associated with vascular injury, such as hypertension, macrophages and leukocytes, themselves rich in NADPH oxidase, invade the vessel and become resident cells in the vascular media. Endothelial cells express mRNA and protein for Nox2, Nox4 and associated regulatory proteins, namely, p22phox, p47phox and p67phox. ${ }^{99}$ Nox2 is the major source of ROS in endothelial cells under basal conditions and in pathological conditions Nox1 and Nox4 may be upregulated. ${ }^{100}$ Nox2, Nox4 and Nox 5 seem to localize primarily in the perinuclear area associated with membranes on the endoplasmic reticulum and nucleus although Nox2 is also found in the plasma membrane within cholesterol-enriched domains, which may serve as signaling platforms for ROS generation in vascular disease. ${ }^{101}$ Vascular smooth muscle cells possess Nox2 (in human resistance arteries) and Nox4, which are major sources of ROS. Nox1, present in low concentrations in basal states, is upregulated in disease. Adventitial fibroblasts possess Nox2 and Nox4 and perivascular adipose tissue expresses Nox4. ${ }^{102,103}$

\section{Nox regulation}

Regulation of Noxes is complex and involves many NADPH oxidase subunits and multiple signaling pathways. All Noxes, except Nox5, seem to have an obligatory need for p22phox. ${ }^{104}$ Whereas Nox2 requires p47phox and p67phox for its activity, Nox1 may interact with homologs of p47phox (NAD $(\mathrm{P}) \mathrm{H}$ oxidase organizer 1) and p67phox (NAD $(\mathrm{P}) \mathrm{H}$ oxidase activator 1$).{ }^{105,106}$ Oxidase activation involves Rac translocation, phosphorylation of $\mathrm{p} 47 \mathrm{phox}$ and its translocation, possibly with p67phox, and p47phox association with cytochrome b558. Nox 2 and Nox4 are constitutively active. However, induction of Nox mRNA expression is observed in response to physical stimuli, (shear stress, pressure), growth factors (plateletderived growth factor, epidermal growth factor and transforming growth factor $\beta$ ), cytokines (tumor necrosis factor- $\alpha$, interleukin-1 and platelet aggregation factor), mechanical forces (cyclic stretch, laminar and oscillatory shear stress), metabolic factors (hyperglycemia, hyperinsulinemia, free fatty acids, advanced glycation end products and $\mathrm{G}$ protein-coupled receptor agonists (serotonin, thrombin, bradykinin, endothelin and Ang II). ${ }^{107-109}$ Nox enzymes are also regulated by ClC-3, Poldip2 and protein disulfide isomerase. Poldip2 associates with p22phox to activate Nox4, leading to regulation of focal adhesion turnover and vascular smooth muscle cell migration, thus linking ROS production and cytoskeletal remodeling. ${ }^{110}$ Ang II an important and potent regulator of cardiovascular $\mathrm{NAD}(\mathrm{P}) \mathrm{H}$ oxidase, activates $\mathrm{NAD}(\mathrm{P}) \mathrm{H}$ oxidase via AT1 receptors through stimulation of signaling pathways involving $\mathrm{c}-\mathrm{Src} \mathrm{p} 21^{\text {Ras }}$, protein kinase $\mathrm{C}$, phospholipase D and phospholipase $\mathrm{A}_{2}{ }^{111-113}$ (Figure 1).

\section{VASCULAR ANTIOXIDANT SYSTEMS}

Enzymatic and non-enzymatic antioxidant systems protect against injurious oxidative stress. Major enzymatic antioxidants found in vascular tissue include SOD, catalase, glutathione peroxidases, thioredoxin and peroxiredoxin. ${ }^{114,115}$ Non-enzymatic antioxidants include ascorbate, tocopherols, glutathione, bilirubin and uric acid and scavenge $\mathrm{OH}$ and other free radicals. ${ }^{116}$ Extracellular SOD, the major vascular SOD, is produced and secreted by vascular smooth muscle cells and binds to glycosaminoglycans in the vascular 
extracellular matrix and regulates oxidant status in the vascular interstitium. ${ }^{114,115}$

Decreased antioxidant capacity promotes cellular oxidative stress and has been implicated in cardiovascular and renal oxidative damage associated with hypertension. ${ }^{114}$ Activity of SOD, catalase and glutathione (GSH) peroxidase is lower and the glutathione disulfide (GSSG)/GSH is higher in plasma and circulating cells from hypertensive patients than normotensive subjects. ${ }^{117}$ In mice deficient in extracellular SOD and in rats in which GSH synthesis is inhibited, blood pressure is significantly elevated, demonstrating that reduced antioxidant capacity is associated with elevated blood pressure. ${ }^{118}$ Failure to upregulate antioxidant genes and reduced antioxidant capacity are also associated with age-accelerated atherosclerosis. ${ }^{119}$

\section{ROS AND VASCULAR BIOLOGY IN HYPERTENSION}

Molecular processes underlying ROS-induced vascular injury involve activation of redox-sensitive signaling pathways. Superoxide anion and $\mathrm{H}_{2} \mathrm{O}_{2}$ stimulate mitogen-activated protein kinases, tyrosine kinases and transcription factors (nuclear factor- $\mathrm{\kappa B}$, activator protein-1 and hypoxia-inducible factor-1) and inactivate protein tyrosine phosphatases. ${ }^{120,121}$ ROS also increase $\left(\mathrm{Ca}^{2+}\right)_{\mathrm{i}}$ and upregulate protooncogene and proinflammatory gene expression and activity ${ }^{122}$ (Figure 2). Virtually all processes involved in the inflammatory response involve ROS. Such phenomena occur through oxidative modification of proteins by altering key amino acid residues, by inducing protein dimerization, and by interacting with metal complexes such as $\mathrm{Fe}-\mathrm{S}$ moieties. ${ }^{123}$

ROS have been implicated in the regulation of vascular tone by modulating vasodilation directly $\left(\mathrm{H}_{2} \mathrm{O}_{2}\right.$ may have vasodilator actions) or indirectly by decreasing nitric oxide bioavailability through quenching by $\bullet \mathrm{O}_{2}{ }^{-}$to form $\mathrm{ONOO}^{-} \cdot{ }^{124-128} \mathrm{ROS}$, through the regulation of hypoxia-inducible factor- 1 , are also important in $\mathrm{O}_{2}$ sensing, ${ }^{125}$ which is essential for maintaining normal $\mathrm{O}_{2}$ homeostasis. In pathological conditions ROS are involved in inflammation, endothelial dysfunc-

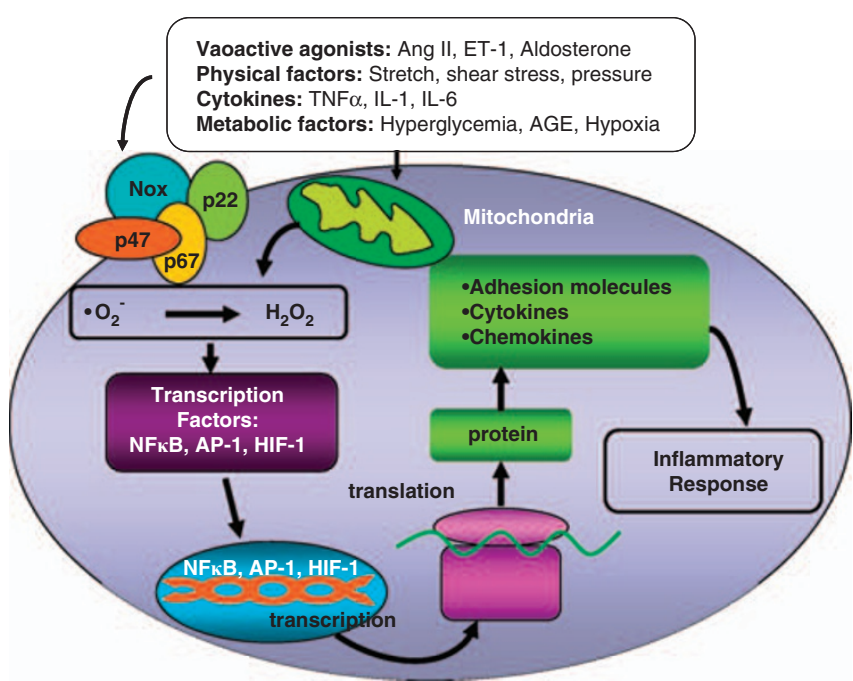

Figure 2 Induction of cellular inflammation by reactive oxygen species (ROS). Generation of ROS in vascular cells by nicotinamide adenine dinucleotide phosphate (NADPH) oxidase or mitochondria, leads to redox signaling that activates transcription factors important in inflammation. AGE, advanced glycation end product; Ang II, angiotensin II; AP-1, activator protein-1; ET-1, endothelin-1; HIF-1; hypoxia-inducible factor-1; IL,

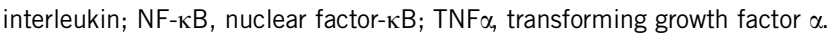

tion, cell proliferation, migration and activation, extracellular matrix deposition, fibrosis, angiogenesis and vascular remodeling ${ }^{129-131}$ (Figure 3).

The causal relationship between ROS and hypertension probably occurs at the vascular level, at least in part, where oxidative stress promotes endothelial dysfunction, vascular inflammation, increased reactivity and structural remodeling leading to increased peripheral resistance and elevated blood pressure. ${ }^{132}$ ROS formation in organs other than the vasculature also contribute to hypertension. Redox signaling in the central nervous system is important in neuronal control of blood pressure. Centrally produced ROS by $\mathrm{NAD}(\mathrm{P}) \mathrm{H}$ oxidase in the hypothalamus and brain stem, nucleus tractus solitarius, subfornical organ, rostral ventrolateral medulla and area postrema are implicated in central control of hypertension, in part through sympathetic outflow. ${ }^{133}$ In experimental hypertension, renal Nox activity and ROS generation are increased and antioxidant enzyme activity/expression is reduced. ${ }^{134}$ Renal oxidative stress is associated with glomerular damage, proteinuria, sodium and volume retention and nephron loss, all important in the development of hypertension. ${ }^{134,135}$

\section{OXIDATIVE STRESS AND HUMAN HYPERTENSION}

Almost all experimental models of hypertension show some form of oxidative excess including genetic forms (spontaneously hypertensive rats, stroke-prone spontaneously hypertensive rats), surgically induced (2K1C, aortic banding), endocrine-induced (Ang II, aldosterone, deoxycorticosterone acetate) and diet-induced hypertension (salt, fat). ${ }^{21-23,136-138}$ Sources of ROS in experimental models include Noxes (Nox1, Nox2 and Nox4), xanthine oxidase, uncoupled nitric oxide synthase and mitochondrial oxidases. Mice deficient in ROSgenerating enzymes have lower blood pressure compared with wild-type counterparts, and Ang II infusion fails to induce hypertension in these mice. ${ }^{139,140}$

Plasma levels of oxidative markers are increased in patients with essential hypertension, renovascular hypertension, malignant hypertension, salt-sensitive hypertension, cyclosporine-induced hypertension and preeclampsia. ${ }^{141-143}$ These findings are based, in general, on increased levels of plasma thiobarbituric acid-reactive substances and 8-epi-isoprostanes, biomarkers of lipid peroxidation and oxidative stress. ${ }^{14-146}$ Polymorphonuclear leukocyte- and platelet-derived $\cdot \mathrm{O}_{2}{ }^{-}$, which also participate in vascular oxidative stress and inflammation, are increased in hypertensive patients. ${ }^{147}$

Hypertensive patients exhibit a significantly higher production of plasma $\mathrm{H}_{2} \mathrm{O}_{2}$ than normotensive subjects. ${ }^{148}$ Additionally, normotensive subjects with a family history of hypertension have greater $\mathrm{H}_{2} \mathrm{O}_{2}$ production than blood pressure-matched normotensives without a family history of hypertension, suggesting that there may be a genetic component that leads to elevated production of $\mathrm{H}_{2} \mathrm{O}_{2} \cdot{ }^{149,150}$ Plasma levels of asymmetric dimethylarginine (endothelial nitric oxide synthase inhibitor) and the lipid peroxidation product of linoleic acid, 13-hydroxyoctadecadienoic acid, a marker of ROS production, were inversely correlated with microvascular endothelial dysfunction and elevated blood pressure in hypertensive patients. To further support a relationship between oxidative stress and blood pressure, Van et al. ${ }^{151}$ recently showed that myeloperoxidase is positively and independently associated with blood pressure and that this association is strongest in subjects with increased levels of oxidative markers. Phagocytic NADPH oxidase activity is increased in obese subjects, possibly due to hyperleptinemia, and is related to vascular remodeling and preclinical atherosclerosis, risk factors associated with hypertension. ${ }^{152}$ 


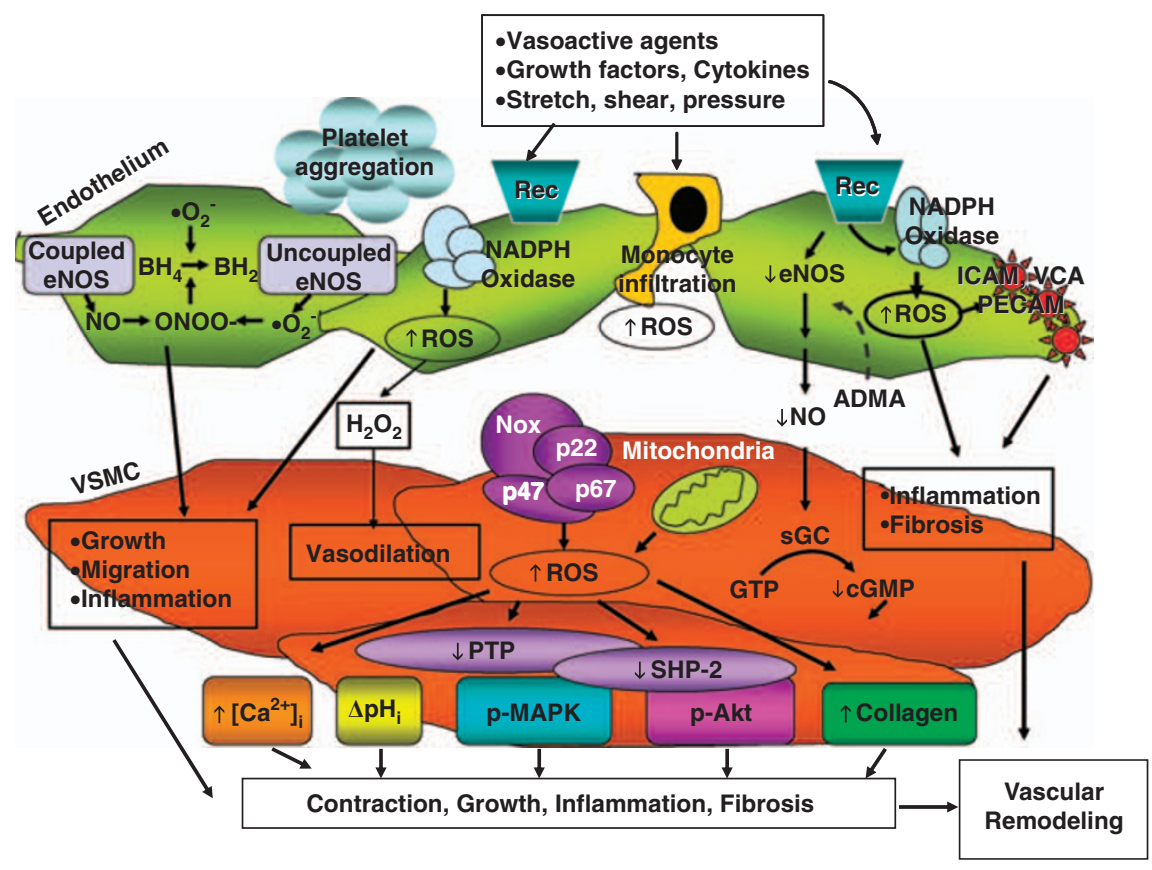

Figure 3 Redox-sensitive mechanisms underlying vascular changes in hypertension. Activation of reactive oxygen species (ROS)-generating enzymes, such as $\mathrm{NAD}(\mathrm{P}) \mathrm{H}$ oxidase, uncoupling of NOS and mitochondrial enzymes in endothelial and vascular smooth muscle cells results in decreased nitric oxide (NO) production and increased generation of $\bullet_{2}^{-}$and $\mathrm{H}_{2} \mathrm{O}_{2}$, which in turn influence redox-sensitive signaling molecules including MAPKs, PTPs, ion channels, transcription factors as well as induction of pro-inflammatory adhesion molecules such as platelet/endothelial cell adhesion molecule (PECAM), intercellular adhesion molecules (ICAM) and vascular cell adhesion molecules (VCAM). These processes lead to vascular growth, fibrosis, contraction/dilation, inflammation and platelet aggregation, which underlie vascular damage and structural remodeling in hypertension and other cardiovascular diseases. ADMA, asymmetric $N(G), N(G)$-dimethyl-L-arginine, endogenous NOS inhibitor; BH4, tetrahydrobiopterin; cGDP, cyclic guanosine diphosphate; eNOS, endothelial nitric oxide synthase; GTP, guanosine triphosphate; MAPK, mitogen-activated protein kinases; p-, phosphorylated protein; NADPH, nicotinamide adenine dinucleotide phosphate; PTP, protein tyrosine phosphatase; Rec, receptor; SGC, soluble guanylyl cyclase; SHP-2, SH2 domain-containing protein tyrosine phosphatase-2; VSMC, vascular smooth muscle cells.

We showed that ROS production is increased in vascular smooth muscle cells from resistance arteries of hypertensive patients and that this is associated with upregulation of vascular $\mathrm{NAD}(\mathrm{P}) \mathrm{H}$ oxidase. ${ }^{153,154}$ The importance of this oxidase in oxidative stress in human cardiovascular disease is supported by studies showing that polymorphisms in $\mathrm{NAD}(\mathrm{P}) \mathrm{H}$ oxidase subunits are associated with increased atherosclerosis and hypertension. ${ }^{155}$ In particular, the -930(A/G) polymorphism in the $\mathrm{p} 22$ (phox) promoter may be a novel genetic marker associated with hypertension. ${ }^{155,156}$ p22(phox) -930A/ G, A640G and C242T polymorphisms of NADPH oxidase have are also associated with peripheral and central pressures in healthy, normotensive individuals. ${ }^{52}$ Polymorphisms $-337 \mathrm{GA}$ and $565+64 \mathrm{CT}$ of xanthine oxidase gene are related to blood pressure and oxidative stress in hypertension, also supporting a role for xanthine oxidase/ROS in hypertension.

Decreased antioxidant capacity also contributes to oxidative stress in patients with hypertension. Hypertensive patients have reduced activity and decreased content of antioxidant enzymes, including SOD, glutathione peroxidase and catalase. ${ }^{157,158}$ Decreased levels of antioxidant vitamins $\mathrm{A}, \mathrm{C}$ and $\mathrm{E}$ have been demonstrated in newly diagnosed, untreated hypertensive patients compared with normotensive controls. ${ }^{158}$ Moreover, SOD activity has been demonstrated to correlate inversely with blood pressure in patients with hypertension. ${ }^{158}$ In patients with white coat hypertension serum protein carbonyl (indicating protein oxidation) was increased and endogenous antioxidant proteins (protein thiol, SOD, glutathione) were decreased compared with normotensive individuals, suggesting a relationship between oxidative stress and hypertension. ${ }^{159}$ Antioxidant vitamins reduced blood pressure and arterial stiffness in patients with diabetes or hypertension in small clinical studies, ${ }^{160}$ but had no effect in postmenopausal women, in healthy subjects or in pregnant women at risk for hypertension/preeclampsia. ${ }^{159-162}$

\section{THERAPEUTIC POTENTIAL OF ROS MODULATORS IN HYPERTENSION}

The potential of antioxidants in treating conditions associated with oxidative stress is supported by experimental investigations, observational findings, small clinical studies and epidemiological data. ${ }^{161,162}$ However, findings are inconsistent and clinical trial data are inconclusive. ${ }^{163-165}$ In general results of clinical studies investigating cardiovascular effects of antioxidants have been disappointing given the consistent and promising findings from experimental investigations. Reasons for this have been extensively reviewed. ${ }^{166-169}$ Harrison and colleagues ${ }^{170}$ proposed a new strategy to increase antioxidant capacity without the use of exogenous antioxidants. They suggest that drugs that selectively inhibit multidrug resistant protein 1 would prevent cellular glutathione loss and thereby protect against oxidative damage, endothelial dysfunction and hypertension. ${ }^{170}$ Whether such an approach is feasible in hypertensive patients remains to be proven.

Theoretically, agents that reduce oxidant formation should be more efficacious than non-specific, inefficient antioxidant vitamin scavengers. This is based on experimental evidence, in which it has been demonstrated that inhibition of Nox-mediated $\bullet \mathrm{O}_{2}{ }^{-}$generation, using pharmacological and gene-targeted strategies, leads to regression of vascular remodeling, improved endothelial function, and lowering of blood pressure. ${ }^{171,172}$ In fact Nox isoforms may be attractive 
therapeutic targets for vascular disease. ${ }^{171-173}$ New peptide inhibitors that have been developed to specifically target NADPH oxidases include the 18 amino acid peptide gp91ds-tat, which interferes with Nox and subunit assembly, because nine of the amino acids mimic the region of p22phox that interacts with p47phox. ${ }^{174}$ PR39, a naturally occurring 39 amino acid proline- and arginine-rich peptide that binds to Src homology domain 3 of p47phox also prevents association between p47phox and Nox, thereby inhibiting oxidase assembly and activation. ${ }^{175}$ Specific Nox inhibitors, including GKT136901, which induce allosteric changes, may also be promising candidates to reduce ROS generation. ${ }^{176}$ However, the safety and effectiveness of all of these agents require confirmation in humans.

Another interesting approach is targeting glucose-6-phosphate dehydrogenase, which is a source of NADPH, the substrate for $\mathrm{NAD}(\mathrm{P}) \mathrm{H}$ oxidase. ${ }^{177}$ Inhibition of glucose-6-phosphate dehydrogenase has been shown to ameliorate development of pulmonary hypertension, possibly through decreased oxidative stress. To date only investigational glucose-6-phosphate dehydrogenase inhibitors are available.

Other pharmacological interventions that reduce oxidative stress include: apocynin, a methoxy catechol that is activated by intracellular peroxidases into active metabolites, which inhibit NADPH oxidase, tetrahydrobiopterin (BH4), polyphenols and flavonoids. ${ }^{175}$ Recent studies demonstrated that pycnogenol, a polyphenol and melatonin, protect the vasculature against oxidative damage, independently of blood pressure changes. ${ }^{178,179}$

Some of the beneficial effects of classical antihypertensive agents such as $\beta$-adrenergic blockers, angiotensin-converting enzyme inhibitors, $\mathrm{AT}_{1}$ receptor antagonists and $\mathrm{Ca}^{2+}$ channel blockers may be mediated, in part, by decreasing vascular oxidative stress. ${ }^{180-184}$ These effects have been attributed to direct inhibition of NADPH oxidase activity and to intrinsic antioxidant properties of the drugs.

In view of current data and the lack of evidence to prove the benefits from use of antioxidants to prevent cardiovascular disease, antioxidant supplementation is not recommended for the prevention or treatment of hypertension. ${ }^{185}$ However, most therapeutic guidelines suggest that the general population consumes a diet emphasizing antioxidant-rich fruits and vegetables and whole grains. ${ }^{186,187}$ Another important lifestyle modification that may have cardiovascular protective and blood pressure lowering effects by reducing oxidative stress is exercise. In experimental models of hypertension and in patients with coronary artery disease, exercise reduced vascular $\mathrm{NAD}(\mathrm{P}) \mathrm{H}$ oxidase activity and ROS production, ameliorated vascular injury and reduced blood pressure. ${ }^{188,189}$

\section{CONCLUSIONS}

Extensive data confirm the importance of ROS in the physiological control of vascular function, through regulation of endothelial function and vascular tone via tightly controlled redox-sensitive signaling pathways. Uncontrolled production/degradation of ROS results in oxidative stress, which induces cardiovascular, renal and neural damage with associated increase in blood pressure. Although oxidative damage may not be the sole cause of hypertension, it facilitates and augments blood pressure elevation in the presence of other pro-hypertensive factors, such as salt-loading, activation of the renin-angiotensin system and sympathetic hyperactivity. Compelling findings from experimental and animal studies suggest a role for oxidative stress in the pathogenesis of hypertension, possibly through increased activation of Noxes. The exact role of specific Nox isoforms however remains unclear. From a clinical viewpoint current data on the causative role of ROS in hypertension are less conclusive. This may relate to heterogeneity of populations studied, inappropriate or insensitive methodologies to evaluate oxidative state clinically and sub-optimal antioxidant therapies used. Further research in the field of oxidative stress and human hypertension is warranted. In particular, there is an urgent need for the development of sensitive and specific biomarkers to assess the oxidant status of patients. Also needed are clinical trials designed to specifically address the role of oxidative stress in the development of hypertension. With a better understanding of mechanisms regulating ROS metabolism and identification of processes that promote oxidative excess, it should be possible to target therapies more effectively so that detrimental vascular actions of oxygen free radicals can be reduced and beneficial effects of nitric oxide can be enhanced.

\section{ACKNOWLEDGEMENTS}

This study was supported by grants 44018 and 57886, both from the Canadian Institutes of Health Research.

1 Kakar P, Lip GY. Towards understanding the aetiology and pathophysiology of human hypertension: where are we now? J Hum Hypertens 2006; 20: 833-836.

2 Touyz RM. Molecular and cellular mechanisms in vascular injury in hypertension: role of angiotensin II. Curr Opin Nephrol Hypertens 2005; 14: 125-131.

3 Harris DM, Cohn HI, Pesant S, Eckhart AD. GPCR signalling in hypertension: role of GRKs. Clin Sci (Lond) 2008; 115: 79-89.

4 Viel EC, Lemarié CA, Benkirane K, Paradis P, Schiffrin EL. Immune regulation and vascular inflammation in genetic hypertension. Am J Physiol Heart Circ Physiol 2010; 298: H938-H944.

5 Sedeek M, Hébert RL, Kennedy CR, Burns KD, Touyz RM. Molecular mechanisms of hypertension: role of Nox family NADPH oxidases. Curr Opin Nephrol Hypertens 2009; 18: $122-127$.

6 Touyz RM, Schiffrin EL. Reactive oxygen species in vascular biology: implications in hypertension. Histochem Cell Biol 2004; 122: 339-352.

7 Droge W. Free radicals in the physiological control of cell function. Physiol Rev 2002; 82: 47-95.

8 Mueller CF, Laude K, McNally JS, Harrison DG. Redox mechanisms in blood vessels. Arterioscler Thromb Vasc Biol 2005; 25: 274-278.

9 Harrison DG, Widder J, Grumbach I, Chen W, Weber M, Searles C. Endothelial mechanotransduction, nitric oxide and vascular inflammation. J Intern Med 2006; 259: 351-363.

10 Vaziri ND, Rodriguez-Iturbe B. Mechanisms of disease: oxidative stress and inflammation in the pathogenesis of hypertension. Nat Clin Pract Nephrol 2006; 2: 582-593.

11 Landmesser U, Harrison DG, Drexler H. Oxidant stress-a major cause of reduced endothelial nitric oxide availability in cardiovascular disease. Eur J Clin Pharmacol 2006; 62: 13-19.

12 Romanowski A, Murray IR, Huston MJ. Effects of hydrogen peroxide on normal and hypertensive rats. Pharm Acta Helv 1960; 35: 354-357.

13 Rajagopalan S, Kurz S, Munzel T, Tarpey M, Freeman BA, Griendling KK, Harrison DG. Angiotensin II-mediated hypertension in the rat increases vascular superoxide production via membrane NADH/NAD(P)H oxidase activation. Contribution to alterations of vasomotor tone. J Clin Invest 1996; 97: 1916-1923.

14 Zalba G, Beaumont FJ, San Jose G, Fortuno A, Fortuno MA, Etayo JC, Díez J. Vascular NADH/NAD(P)H oxidase is involved in enhanced superoxide production in spontaneously hypertensive rats. Hypertension 2000; 35: 1055-1061.

15 Akasaki T, Ohya Y, Kuroda J, Eto K, Abe I, Sumimoto H, lida M. Increased expression of gp91phox homologues of $\mathrm{NAD}(\mathrm{P}) \mathrm{H}$ oxidase in the aortic media during chronic hypertension: involvement of the renin-angiotensin system. Hypertens Res 2006; 29: 813-820.

16 Jung O, Schreiber JG, Geiger H, Pedrazzini T, Busse R, Brandes RP. NAD(P)H oxidase mediates endothelial dysfunction in renovascular hypertension. Circulation 2004; 109: 1795-1801.

17 Kagota S, Tada Y, Kubota Y, Nejime N, Yamaguchi Y, Nakamura K, Kunitomo M, Shinozuka K. Peroxynitrite is involved in the dysfunction of vasorelaxation in SHR/ NDmcr-cp rats, spontaneously hypertensive obese rats. J Cardiovasc Pharmacol 2007; 50: 677-685.

18 Landmesser U, Cai H, Dikalov S, McCann L, Hwang J, Jo H, Holland SM, Harrison DG. Role of $\mathrm{p} 47$ (phox) in vascular oxidative stress and hypertension caused by angiotensin II. Hypertension 2002; 40: 511-515.

19 Virdis A, Neves MF, Amiri F, Touyz RM, Schiffrin EL. Role of NAD(P)H oxidase on vascular alterations in angiotensin II-infused mice. J Hypertens 2004; 22: 535-542.

20 Diep QN, Amiri F, Touyz RM, Cohn JS, Endemann D, Neves MF, Schiffrin EL. PPARa activator effects on Ang II-induced vascular oxidative stress and inflammation. Hypertension 2002; 40: 866-871. 
21 Lavi S, Yang EH, Prasad A, Mathew V, Barsness GW, Rihal CS, Lerman LO, Lerman A. The interaction between coronary endothelial dysfunction, local oxidative stress, and endogenous nitric oxide in humans. Hypertension 2008; 51: 127-133.

22 Franco MC, Kawamoto EM, Gorjão R, Rastelli VM, Curi R, Scavone C, Sawaya AL, Fortes ZB, Sesso R. Biomarkers of oxidative stress and antioxidant status in children born small for gestational age: evidence of lipid peroxidation. Pediatr Res 2007; 62: 204-208.

23 Cottone S, Mulè G, Guarneri M, Palermo A, Lorito MC, Riccobene R, Arsena R, Vaccaro F, Vadalà A, Nardi E, Cusimano P, Cerasola G. Endothelin-1 and F2-isoprostane relate to and predict renal dysfunction in hypertensive patients. Nephrol Dial Transplant 2009; 24: 497-503.

24 Mistry HD, Wilson V, Ramsay MM, Symonds ME, Broughton Pipkin F. Reduced selenium concentrations and glutathione peroxidase activity in preeclamptic pregnancies. Hypertension 2008; 52: 881-888.

25 Duffy SJ, Gokce N, Holbrook M, Huang A, Frei B, Keaney Jr JF, Vita JA. Treatment of hypertension with ascorbic acid. Lancet 1999; 354: 2048-2049.

26 Duffy SJ, Gokce N, Holbrook M, Hunter LM, Biegelsen ES, Huang A, Keaney Jr JF, Vita JA. Effect of ascorbic acid treatment on conduit vessel endothelial dysfunction in patients with hypertension. Am J Physiol Heart Circ Physiol 2001; 280: H528-H534.

27 Darko D, Dornhorst A, Kelly FJ, Ritter JM, Chowienczyk PJ. Lack of effect of oral vitamin $C$ on blood pressure, oxidative stress and endothelial function in type II diabetes. Clin Sci (Lond) 2002; 103: 339-344.

28 Hatzitolios A, Iliadis F, Katsiki N, Baltatzi M. Is the anti-hypertensive effect of dietary supplements via aldehydes reduction evidence based? A systematic review. Clin Exp Hypertens 2008; 30: 628-639.

29 Wray DW, Uberoi A, Lawrenson L, Bailey DM, Richardson RS. Oral antioxidants and cardiovascular health in the exercise-trained and untrained elderly: a radically different outcome. Clin Sci (Lond) 2009; 116: 433-441.

30 Fridovich I. Superoxide anion radical (02-.), superoxide dismutases, and related matters. J Biol Chem 1997; 272: 18515-18517.

31 Lob HE, Marvar PJ, Guzik TJ, Sharma S, McCann LA, Weyand C, Gordon FJ, Harrison DG. Induction of hypertension and peripheral inflammation by reduction of extracellular superoxide dismutase in the central nervous system. Hypertension 2010; 55: 277-283.

32 Nistala R, Wei Y, Sowers JR, Whaley-Connell A. Renin-angiotensin-aldosterone system-mediated redox effects in chronic kidney disease. Trans/ Res 2009; 153: 102-113.

33 Johnson F, Giulivi C. Superoxide dismutases and their impact upon human health. Mol Aspects Med 2005; 26: 340-352.

34 Faraci FM, Didion SP. Vascular protection: superoxide dismutase isoforms in the vessel wall. Arterioscler Thromb Vasc Biol 2004; 24: 1367-1373.

35 Mendez JI, Nicholson WJ, Taylor WR. SOD isoforms and signaling in blood vessels: evidence for the importance of ROS compartmentalization. Arterioscler Thromb Vasc Biol 2005; 25: 887-888.

36 Welch WJ, Chabrashvili T, Solis G, Chen Y, Gill PS, Aslam S, Wang X, $\mathrm{Ji} \mathrm{H}$, Sandberg K, Jose P, Wilcox CS. Role of extracellular superoxide dismutase in the mouse angiotensin slow pressor response. Hypertension 2006; 48: 934-941.

37 Nishino T, Okamoto K, Eger BT, Pai EF, Nishino T. Mammalian xanthine oxidoreductase-mechanism of transition from xanthine dehydrogenase to xanthine oxidase. FEBS J 2008; 275: 3278-3289.

38 Seshiah PN, Weber DS, Rocic P, Valppu L, Taniyama Y, Griendling KK. Angiotensin II stimulation of $\mathrm{NAD}(\mathrm{P}) \mathrm{H}$ oxidase activity: upstream mediators. Circ Res 2002; 91 : 406-413.

39 Adlam D, Bendall JK, De Bono JP, Alp NJ, Khoo J, Nicoli T, Yokoyama M, Kawashima $\mathrm{S}$, Channon KM. Relationships between nitric oxide-mediated endothelial function, eNOS coupling and blood pressure revealed by eNOS-GTP cyclohydrolase 1 double transgenic mice. Exp Physiol 2007; 92: 119-126.

40 Moens AL, Kass DA. Tetrahydrobiopterin and cardiovascular disease. Arterioscler Thromb Vasc Biol 2006; 26: 2439-2444

41 Liu Y, Zhao H, Li H, Kalyanaraman B, Nicolosi AC, Gutterman DD. Mitochondrial sources of $\mathrm{H} 2 \mathrm{O} 2$ generation play a key role in flow-mediated dilation in human coronary resistance arteries. Circ Res 2003; 93: 573-580.

42 DeLano FA, Parks DA, Ruedi JM, Babior BM, Schmid-Schonbein GW. Microvascular display of xanthine oxidase and $\mathrm{NAD}(\mathrm{P}) \mathrm{H}$ oxidase in the spontaneously hypertensive rat. Microcirculation 2006; 13: 551-566.

43 Feig DI, Soletsky B, Johnson RJ. Effect of allopurinol on blood pressure of adolescents with newly diagnosed essential hypertension: a randomized trial. JAMA 2008; 300: 924-932.

44 Landmesser U, Dikalov S, Price SR, McCann L, Fukai T, Holland SM. Oxidation of tetrahydrobiopterin leads to uncoupling of endothelial cell nitric oxide synthase in hypertension. J Clin Invest 2003; 111: 1201-1209.

45 Brand MD, Affourtit C, Esteves TC, Green K, Lambert AJ, Miwa S, Pakay JL, Parker N. Mitochondrial superoxide: production, biological effects, and activation of uncoupling proteins. Free Radic Biol Med 2004; 37: 755-767.

46 James AM, Murphy MP. How mitochondrial damage affects cell function. J Biomed Sci 2002; 9: 475-487.

47 Mari M, Caballero F, Colell A, Morales A, Caballeria J, Fernandez A, Enrich C, Fernandez-Checa JC, Garcia-Ruiz C. Mitochondrial free cholesterol loading sensitizes to TNF- and Fas-mediated steatohepatitis. Cell Metab 2006; 4: 185-198.

48 Wosniak J, Santos CX, Kowaltowski AJ, Laurindo FR. Cross-talk between mitochondria and $\mathrm{NAD}(\mathrm{P}) \mathrm{H}$ oxidase: effects of mild mitochondrial dysfunction on angiotensin II-mediated increase in Nox isoform expression and activity in vascular smooth muscle cells. Antioxid Redox Signal 2009; 11: 1265-1278.
49 Nozoe M, Hirooka Y, Koga Y, Araki S, Konno S, Kishi T, Ide T, Sunagawa K. Mitochondria-derived reactive oxygen species mediate sympathoexcitation induced by angiotensin II in the rostral ventrolateral medulla. J Hypertens 2008; 26: 2176-2184.

50 Fernandez-Patron C. Therapeutic potential of the epidermal growth factor receptor transactivation in hypertension: a convergent signaling pathway of vascular tone, oxidative stress, and hypertrophic growth downstream of vasoactive G-protein-coupled receptors? Can J Physiol Pharmacol 2007; 85: 97-104.

51 Zhang GX, Lu XM, Kimura S, Nishiyama A. Role of mitochondria in angiotensin Il-induced reactive oxygen species and mitogen-activated protein kinase activation. Cardiovasc Res 2007; 76: 204-212.

52 Gunter TE, Pfeiffer DR. Mechanisms by which mitochondria transport calcium. Am J Physiol 1990; 258: C755-C786.

53 Zoratti M, Szabo I. The mitochondrial permeability transition. Biochim Biophys Acta 1995; 1241: 139-176.

54 Doughan AK, Harrison DG, Dikalov SI. Molecular mechanisms of angiotensin II-mediated mitochondrial dysfunction: linking mitochondrial oxidative damage and vascular endothelial dysfunction. Circ Res 2008; 102: 488-496.

55 Ungvari Z, Labinskyy N, Gupte S, Chander PN, Edwards JG, Csiszar A. Dysregulation of mitochondrial biogenesis in vascular endothelial and smooth muscle cells of aged rats. Am J Physiol Heart Circ Physiol 2008; 294: H2121-H2128.

56 Postnov YV, Orlov SN, Budnikov YY, Doroschuk AD, Postnov AY. Mitochondrial energy conversion disturbance with decrease in ATP production as a source of systemic arterial hypertension. Pathophysiology 2007; 14: 195-204.

57 Zhang H, Luo Y, Zhang W, He Y, Dai S, Zhang R, Huang Y, Bernatchez P, Giordano FJ, Shadel G, Sessa WC, Min W. Endothelial-specific expression of mitochondrial thioredoxin improves endothelial cell function and reduces atherosclerotic lesions. Am J Pathol 2007; 170: 1108-1120.

58 Rodriguez-Iturbe B, Sepassi L, Quiroz Y, Ni Z, Wallace DC, Vaziri ND. Association of mitochondrial SOD deficiency with salt-sensitive hypertension and accelerated renal senescence. J App/ Physiol 2007; 102: 255-260.

59 Zorov DB, Juhaszova M, Sollott SJ. Mitochondrial ROS-induced ROS release: an update and review. Biochim Biophys Acta 2006; 1757: 509-517.

60 de Cavanagh EM, Inserra F, Ferder M, Ferder L. From mitochondria to disease: role of the renin-angiotensin system. Am J Nephrol 2007; 27: 545-553.

61 Touyz RM, Yao G, Viel E, Amiri F, Schiffrin EL. Angiotensin II and endothelin-1 regulate MAP kinases through different redox-dependent mechanisms in human vascular smooth muscle cells. J Hypertens 2004; 22: 1141-1149.

62 Callera GE, Tostes RC, Yogi A, Montezano AC, Touyz RM. Endothelin-1-induced oxidative stress in DOCA-salt hypertension involves NADPH-oxidase-independent mechanisms. Clin Sci (Lond) 2006; 110: 243-253.

63 Yang Q, Kim SK, Sun F, Cui J, Larson MG, Vasan RS, Levy D, Schwartz F. Maternal influence on blood pressure suggests involvement of mitochondrial DNA in the pathogenesis of hypertension: the Framingham Heart Study. J Hypertens 2007; 25: 2067-2073.

64 Rachek LI, Grishko VI, LeDoux SP, Wilson GL. Role of nitric oxide-induced mtDNA damage in mitochondrial dysfunction and apoptosis. Free Radic Biol Med 2006; 40: 754-762.

65 Puddu P, Puddu GM, Cravero E, De PS, Muscari A. The putative role of mitochondrial dysfunction in hypertension. Clin Exp Hypertens 2007; 29: 427-434.

66 Miller AA, Drummond GR, Sobey CG. Novel isoforms of NADPH-oxidase in cerebral vascular control. Pharmacol Ther 2006; 111: 928-948.

67 Dworakowski R, Alom-Ruiz SP, Shah AM. NADPH oxidase-derived reactive oxygen species in the regulation of endothelial phenotype. Pharmacol Rep 2008; 60: 21-28.

$68 \mathrm{Li} \mathrm{JM}$, Shah AM. Intracellular localization and preassembly of the NAD(P)H oxidase complex in cultured endothelial cells. J Biol Chem 2002; 277: 19952-19960.

69 Babior BM. NAD(P)H oxidase. Curr Opin Immunol 2004; 16: 42-47.

70 Vignais $\mathrm{PV}$. The superoxide-generating $\mathrm{NAD}(\mathrm{P}) \mathrm{H}$ oxidase: structural aspects and activation mechanism. Cell Mol Life Sci 2002; 59: 1428-1459.

71 Taura M, Miyano K, Minakami R, Kamakura S, Takeya R, Sumimoto H. A region $\mathrm{N}$-terminal to the tandem SH3 domain of $\mathrm{p} 47$ phox plays a crucial role in the activation of the phagocyte NAD(P)H oxidase. Biochem J 2009; 419: 329-338.

72 Bokoch GM, Zhao T. Regulation of the phagocyte NAD(P)H oxidase by Rac GTPase. Antioxid Redox Signal 2006; 8: 1533-1548.

73 Geiszt M. NAD(P)H oxidases: new kids on the block. Cardiovasc Res 2006; 71: 289-299.

74 Cave AC, Brewer AC, Panicker AN, Ray R, Grieve DJ, Walker S, Shah AM. NAD(P)H oxidases in cardiovascular health and disease. Antiox Redox Sig 2006; 8: 691-727.

75 Guzik TJ, Chen W, Gongora MC, Guzik B, Lob HE, Mangalat D, Hoch N, Dikalov S, Rudzinski P, Kapelak B, Sadowski J, Harrison DG. Calcium-dependent NOX5 nicotinamide adenine dinucleotide phosphate oxidase contributes to vascular oxidative stress in human coronary artery disease. J Am Coll Cardiol 2008; 52: 1803-1809.

76 Lassègue $B$, Griendling KK. NADPH oxidases: functions and pathologies in the vasculature. Arterioscler Thromb Vasc Biol 2010; 30: 653-661.

77 Santos CX. Tanaka LY, Wosniak J, Laurindo FR. Mechanisms and implications of reactive oxygen species generation during the unfolded protein response: roles of endoplasmic reticulum oxidoreductases, mitochondrial electron transport, and NADPH oxidase. Antioxid Redox Signal 2009; 11: 2409-2427.

78 Nisimoto Y, Tsubouchi R, Diebold BA, Qiao S, Ogawa H, Ohara T, Tamura M. Activation of $\mathrm{NAD}(\mathrm{P}) \mathrm{H}$ oxidase 1 in tumour colon epithelial cells. Biochem J 20081; 415: $57-65$.

79 Muzaffar S, Shukla N, Bond M, Newby AC, Angelini GD, Sparatore A, Del Soldato P, Jeremy JY. Exogenous hydrogen sulfide inhibits superoxide formation, NOX-1 
expression and Rac1 activity in human vascular smooth muscle cells. J Vasc Res 2008; 45: 521-528.

80 Fernandes DC, Manoel AHO, Wosniak J, Laurindo FR. Protein disulfide isomerise overexpression in vascular smooth muscle cells induces spontaneous preemptive NAD $(P) H$ oxidase activation nad Nox1 mRNA expression: effects of nitrosothiol exposure. Arch Biochem Biophys 2009; 484: 197-204.

81 Lee MY, San Martin A, Mehta PK, Dikalova AE, Garrido AM, Datla SR, Lyons E, Krause KH, Banfi B, Lambeth JD, Lassègue $B$, Griendling KK. Mechanisms of vascular smooth muscle $\mathrm{NAD}(\mathrm{P}) \mathrm{H}$ oxidase 1 (Nox1) contribution to injury-induced neointimal formation. Arterioscler Thromb Vasc Biol 2009; 29: 480-487.

82 Chabrashvili T, Tojo A, Onozato ML, Kitiyakara C, Quinn MT, Fujita T, Welch WJ, Wilcox CS. Expression and cellular localization of classic NAD(P)H oxidase subunits in the spontaneously hypertensive rat kidney. Hypertension 2002; 39: 269-274.

83 Lassegue B, Clempus RE. Vascular NAD(P)H oxidases: specific features, expression, and regulation. Am J Physiol Regul Integr Comp Physiol 2003; 285: R277-R297.

84 Touyz RM, Chen X, Tabet F, Yao G, He G, Quinn MT, Pagano PJ, Schiffrin EL. Expression of a functionally active gp91phox-containing neutrophil-type $N A D(P) H$ oxidase in smooth muscle cells from human resistance arteries: regulation by angiotensin II. Circ Res 2002; 90: 1205-1213.

85 Liu KL. Regulation of renal medullary circulation by the renin-angiotensin system in genetically hypertensive rats. Clin Exp Pharmacol Physiol 2009; 36: 455-461.

86 Gupte SA, Kaminski PM, George S, Kouznestova L, Olson SC, Mathew R, Hintze TH, Wolin MS. Peroxide generation by p47phox-Src activation of Nox2 has a key role in protein kinase C-induced arterial smooth muscle contraction. Am J Physiol Heart Circ Physiol 2009; 296: H1048-H1057.

87 Kawahara T, Lambeth JD. Molecular evolution of Phox-related regulatory subunits for NAD(P)H oxidase enzymes. BMC Evol Biol 2007; 7: 178-181.

88 Petry A, Djordjevic T, Weitnauer M, Kietzmann T, Hess J, Görlach A. NOX2 and NOX4 mediate proliferative response in endothelial cells. Antioxid Redox Signal 2006; 8: 1473-1484.

89 Kuroda J, Nakagawa K, Yamasaki T, Nakamura K, Takeya R, Kuribayashi F, ImajohOhmi S, Igarashi K, Shibata Y, Sueishi K, Sumimoto H. superoxide-producing $\mathrm{NAD}(\mathrm{P}) \mathrm{H}$ oxidase Nox4 in the nucleus of human vascular endothelial cells. Genes Cells 2005; 10: 1139-1151.

90 Chen K Kirber MT, Xiao H, Yang Y, Keaney Jr JF. Regulation of ROS signal transduction by NAD(P)H oxidase 4 localization. J Cell Biol 2008; 181: 1129-1139.

91 Clempus RE, Sorescu D, Dikalova AE, Pounkova L, Jo P, Sorescu GP, Schmidt HH, Lassègue $B$, Griendling KK. Nox4 is required for maintenance of the differentiated vascular smooth muscle cell phenotype. Arterioscler Thromb Vasc Biol 2007; 27: 42-48.

92 Serrander L, Jaquet V, Bedard K, Plastre O, Hartley O, Arnaudeau S, Demaurex N, Schlegel W, Krause KH. NOX5 is expressed at the plasma membrane and generates superoxide in response to protein kinase C activation. Biochimie 2007; 89: 1159-1167.

93 Jagnandan D, Church JE, Banfi B, Stuehr DJ, Marrero MB, Fulton DJ. Novel mechanism of activation of $\mathrm{NAD}(\mathrm{P}) \mathrm{H}$ oxidase 5 . Calcium sensitization via phosphorylation. J Biol Chem 2007; 282: 6494-6507.

94 Si J, Fu X, Behar J, Wands J, Beer DG, Souza RF, Spechler SJ, Lambeth D, Cao W. NAD(P)H oxidase NOX5-S mediates acid-induced cyclooxygenase-2 expression via activation of NF-kappaB in Barrett's esophageal adenocarcinoma cells. J Biol Chem 2007; 282: 16244-16255.

95 BelAiba RS, Djordjevic T, Petry A, Diemer K, Bonello S, Banfi B, Hess J, Pogrebniak A, Bickel C, Görlach A. NOX5 variants are functionally active in endothelial cells. Free Radic Biol Med 2007; 42: 446-459.

96 Schulz E, Münzel T. NOX5, a new 'radical' player in human atherosclerosis? J Am Coll Cardiol 2008; 52: 1810-1812.

97 Jay DB, Papaharalambus CA, Seidel-Rogol B, Dikalova AE, Lassègue B, Griendling KK. Nox5 mediates PDGF-induced proliferation in human aortic smooth muscle cells. Free Radic Biol Med 2008; 45: 329-335.

98 Montezano AC, Paravicini TM, Chignalia AZ, Yusuf H, Almasri M, He Y, He G, Callera GE, Krause K-H, Lambeth D, Touyz RM. Nicotinamide adenine dinucleotide phosphate reduced oxidase 5 (Nox5) regulation by angiotensin II and endothelin- 1 is mediated via calcium/calmodulin-dependent pathways in human endothelial cells. Circ Res 2010; 106: 1363-1373.

99 Selemidis S, Sobey CG, Wingler K, Schmidt HH. Drummond GR NAD(P)H oxidases in the vasculature: molecular features, roles in disease, pharmacological inhibition. Pharmacol Ther 2008; 120: 254-291.

100 Li S, Tabar SS, Malec V, Eul BG, Klepetko W, Weissmann N, Grimminger F, Seeger W, Rose F, Hänze J. NOX4 regulates ROS levels under normoxic and hypoxic conditions, triggers proliferation, and inhibits apoptosis in pulmonary artery adventitial fibroblasts. Antioxid Redox Signal 2008; 10: 1687-1698.

101 Hilenski LL, Clempus RE, Quinn MT, Lambeth JD, Griendling KK. Distinct subcellular localizations of Nox1 and Nox4 in vascular smooth muscle cells. Arterioscler Thromb Vasc Biol 2004; 24: 677-683.

102 Schröder K, Wandzioch K, Helmcke I, Brandes RP. Nox4 acts as a switch between differentiation and proliferation in preadipocytes. Arterioscler Thromb Vasc Biol 2009; 29: 239-245.

103 Gao YJ, Takemori K, Su LY, An WS, Lu C, Sharma AM, Lee RM. Perivascular adipose tissue promotes vasoconstriction: the role of superoxide anion. Cardiovasc Res 2006; 71: 363-373.

104 Takeya R, Sumimoto H. Regulation of novel superoxide-producing NAD(P)H oxidases. Antioxid Redox Signal 2006; 8: 1523-1532.
105 Ambasta RK, Schreiber JG, Janiszewski M, Busse R, Brandes RP. Noxa1 is a central component of the smooth muscle $\mathrm{NAD}(\mathrm{P}) \mathrm{H}$ oxidase in mice. Free Radic Biol Med 2006; 41: 193-201.

106 Cheng G, Lambeth JD. Alternative mRNA splice forms of NOXO1: differential tissue expression and regulation of Nox1 and Nox3. Gene 2005; 356: 118-126.

107 Ibi M, Matsuno K, Shiba D, Katsuyama M, Iwata K, Kakehi T, Nakagawa T, Sango K, Shirai Y, Yokoyama T, Kaneko S, Saito N, Yabe-Nishimura C. Reactive oxygen species derived from NOX1/NAD(P)H oxidase enhance inflammatory pain. J Neurosci 2008; 28: 9486-9494.

108 Peng YJ, Yuan G, Jacono FJ, Kumar GK, Prabhakar NR. 5-HT evokes sensory long-term facilitation of rodent carotid body via activation of $\mathrm{NAD}(\mathrm{P}) \mathrm{H}$ oxidase. J Physiol 2006; 576 (Part 1): 289-295.

109 Brandes RP, Schröder K. Differential vascular functions of Nox family NAD(P)H oxidases. Curr Opin Lipidol 2008; 19: 513-518.

110 Lyle AN, Deshpande NN, Taniyama Y, Seidel-Rogol B, Pounkova L, Du P, Papaharalambus C, Lassègue B, Griendling KK. Poldip2, a novel regulator of Nox4 and cytoskeletal integrity in vascular smooth muscle cells. Circ Res 2009; 105: 249-259.

111 El-Benna J, Dang PM, Gougerot-Pocidalo MA, Marie JC, Braut-Boucher F. p47phox, the phagocyte $\mathrm{NAD}(\mathrm{P}) \mathrm{H}$ oxidase/NOX2 organizer: structure, phosphorylation and implication in diseases. Exp Mol Med 2009; 41: 217-225.

112 Montezano AC, Callera GE, Yogi A, He Y, Tostes RC, He G, Schiffrin EL, Touyz RM. Aldosterone and angiotensin II synergistically stimulate migration in vascular smooth muscle cells through c-Src-regulated redox-sensitive RhoA pathways. Arterioscler Thromb Vasc Biol 2008; 28: 1511-1518.

113 Block K, Eid A, Griendling KK, Lee DY, Wittrant Y, Gorin Y. Nox4 NAD(P)H oxidase mediates Src-dependent tyrosine phosphorylation of PDK-1 in response to angiotensin II: role in mesangial cell hypertrophy and fibronectin expression. J Biol Chem 2008; 283: 24061-24076.

114 Gongora MC, Qin Z, Laude K, Kim HW, McCann L, Folz JR, Dikalov S, Fukai T, Harrison DG. Role of extracellular superoxide dismutase in hypertension. Hypertension 2006; 48: 473-481.

115 Sindhu RK, Ehdaie A, Farmand F, Dhaliwal KK, Nguyen T, Zhan CD, Roberts CK, Vaziri ND. Expression of catalase and glutathione peroxidase in renal insufficiency. Biochim Biophys Acta 2005; 1743: 86-92.

116 Tajima M, Kurashima Y, Sugiyama K, Ogura T, Sakagami H. The redox state of glutathione regulates the hypoxic induction of HIF-1. Eur J Pharmacol 2009; 606: $45-49$.

117 Redon J, Oliva MR, Tormos C, Giner V, Chaves J, Iradi A, Sáez GT. Antioxidant activities and oxidative stress byproducts in human hypertension. Hypertension 2003; 41: 1096-1101.

118 Welch WJ, Chabrashvili T, Solis G, Chen Y, Gill PS, Aslam S, Wang X, Ji H, Sandberg K, Jose P, Wilcox CS. Role of extracellular superoxide dismutase in the mouse angiotensin slow pressor response. Hypertension 2006; 48: 934-941.

119 Collins AR, Lyon CJ, Xia X, Liu JZ, Tangirala RK, Yin F, Boyadjian R, Bikineyeva A, Praticò D, Harrison DG, Hsueh WA. Age-accelerated atherosclerosis correlates with failure to upregulate antioxidant genes. Circ Res 2009; 104: e42-e54.

$120 \mathrm{Hool}$ LC, Corry B. Redox control of calcium channels: from mechanisms to therapeutic opportunities. Antioxid Redox Signal 2007; 9: 409-435.

121 Touyz RM, Tabet F, Schiffrin EL. Redox-dependent signalling by angiotensin II and vascular remodelling in hypertension. Clin Exp Pharmacol Physiol 2003; 30: 860-866.

122 Tabet F, Savoia C, Schiffrin EL, Touyz RM. Differential calcium regulation by hydrogen peroxide and superoxide in vascular smooth muscle cells from spontaneously hypertensive rats. J Cardiovasc Pharmacol 2004; 44: 200-208.

123 Gutierrez J, Ballinger SW, Darley-Usmar VM, Landar A. Free radicals, mitochondria, and oxidized lipids: the emerging role in signal transduction in vascular cells. Circ Res 2006; 99: 924-932.

124 Cohen RA, Adachi T. Nitric-oxide-induced vasodilatation: regulation by physiologic $\mathrm{s}$-glutathiolation and pathologic oxidation of the sarcoplasmic endoplasmic reticulum calcium ATPase. Trends Cardiovasc Med 2006; 16: 109-114.

125 Wolin MS, Gupte SA, Neo BH, Gao Q, Ahmad M. Oxidant-redox regulation of pulmonary vascular responses to hypoxia and nitric oxide-cGMP signaling. Cardiol Rev 2010; 18: 89-93.

126 Gao Q, Zhao X, Ahmad M, Wolin MS. Mitochondrial-derived hydrogen peroxide inhibits relaxation of bovine coronary arterial smooth muscle to hypoxia through stimulation of ERK MAP kinase. Am J Physiol Heart Circ Physiol 2009; 297: H2262-H2269.

127 Takaki A, Morikawa K, Tsutsui M, Murayama Y, Tekes E, Yamagishi H, Ohashi J, Yada T, Yanagihara N, Shimokawa H. Crucial role of nitric oxide synthases system in endothelium-dependent hyperpolarization in mice. J Exp Med 2008; 205: 2053-2063.

128 Matoba T, Shimokawa H, Nakashima M, Hirakawa Y, Mukai Y, Hirano K, Kanaide H, Takeshita A. Hydrogen peroxide is an endothelium-derived hyperpolarizing factor in mice. J Clin Invest 2000; 106: 1521-1530.

129 Chavez A, Miranda LF, Pichiule P, Chavez JC. Mitochondria and hypoxia-induced gene expression mediated by hypoxia-inducible factors. Ann N Y Acad Sci 2008; 1147: 312-320

130 Feissner RF, Skalska J, Gaum WE, Sheu SS. Crosstalk signaling between mitochondrial Ca2+ and ROS. Front Biosci 2009; 14: 1197-1218.

131 Callera GE, Montezano AC, Yogi A, Tostes RC, Touyz RM. Vascular signaling through cholesterol-rich domains: implications in hypertension. Curr Opin Nephrol Hypertens 2007; 16: 90-104. 
132 Harrison DG, Gongora MC, Guzik TJ, Widder J. Oxidative stress and hypertension. JASH 2007; 1: 30-44.

133 Peterson JR, Sharma RV, Davisson RL. Reactive oxygen species in the neuropathogenesis of hypertension. Curr Hypertens Rep 2006; 8: 232-241.

134 Gill PS, Wilcox CS. NAD(P)H oxidases in the kidney. Antioxid Redox Signal 2006; 8: 1597-1607.

135 Wilcox CS. Oxidative stress and nitric oxide deficiency in the kidney: a critical link to hypertension? Am J Physiol Regul Integr Comp Physiol 2005; 289: R913-R935.

136 Nuyt AM. Mechanisms underlying developmental programming of elevated blood pressure and vascular dysfunction: evidence from human studies and experimental animal models. Clin Sci (Lond) 2008; 114: 1-17.

137 Fukai T, Ishizaka N, Rajagopalan S, Laursen JB, Capers QT, Taylor WR. p22phox mRNA expression and $\mathrm{NAD}(\mathrm{P}) \mathrm{H}$ oxidase activity are increased in aortas from hypertensive rats. Circ Res 1997; 80: 45-51.

138 Haque MZ, Majid DS. Reduced renal responses to nitric oxide synthase inhibition in mice lacking the gene for gp91phox subunit of $\mathrm{NAD}(\mathrm{P}) \mathrm{H}$ oxidase. Am J Physiol Renal Physiol 2008; 295: F758-F764.

139 Modlinger P, Chabrashvili T, Gill PS, Mendonca M, Harrison DG, Griendling KK, Li M, Raggio J, Wellstein A, Chen Y, Welch WJ, Wilcox CS. RNA silencing in vivo reveals role of p22phox in rat angiotensin slow pressor response. Hypertension 2006; 47: 238-244.

140 Touyz RM, Mercure C, He Y, Javeshghani D, Yao G, Callera GE, Yogi A, Lochard N, Reudelhuber TL. Angiotensin II-dependent chronic hypertension and cardiac hypertrophy are unaffected by gp91phox-containing NAD(P)H oxidase. Hypertension 2005; 45: 530-537.

141 Fortuno A, Olivan S, Beloqui O, San Jose G, Moreno MU, Diez J, Zalba G. Association of increased phagocytic NAD(P)H oxidase-dependent superoxide production with diminished nitric oxide generation in essential hypertension. J Hypertens 2004; 22 2169-2175.

142 Higashi Y, Sasaki S, Nakagawa K, Matsuura H, Oshima T, Chayama K. Endothelial function and oxidative stress in renovascular hypertension. N Engl J Med 2002; 346: 1954-1962.

143 Ward NC, Hodgson JM, Puddey IB, Mori TA, Beilin LJ, Croft KD. Oxidative stress in human hypertension: association with antihypertensive treatment, gender, nutrition, and lifestyle. Free Radic Biol Med 2004; 36: 226-232.

144 Lee VM, Quinn PA, Jennings SC, Ng LL. Neutrophil activation and production of reactive oxygen species in pre-eclampsia. J Hypertens 2003; 21: 395-402.

145 Ide T, Tsutsui H, Ohashi N, Hayashidani S, Suematsu N, Tsuchihashi M, Tamai H, Takeshita A. Greater oxidative stress in healthy young men compared with premenopausal women. Arterioscler Thromb Vasc Biol 2002; 22: 438-442.

146 Minuz P, Patrignani P, Gaino S, Seta F, Capone ML, Tacconelli S, Degan M, Faccini G, Fornasiero A, Talamini G, Tommasoli R, Arosio E, Santonastaso CL, Lechi A, Patrono C. Determinants of platelet activation in human essential hypertension. Hypertension 2004; 43: 64-70

147 Yasunari K, Maeda K, Nakamura M, Yoshikawa J. Oxidative stress in leukocytes is a possible link between blood pressure, blood glucose, and C-reacting protein. Hypertension 2002; 39: 777-780.

148 Lacy F, Kailasam MT, O'Connor DT, Schmid-Schonbein GW, Parmer RJ. Plasma hydrogen peroxide production in human essential hypertension: role of heredity, gender, and ethnicity. Hypertension 2000; 36: 878-884.

149 Lacy F, O'Connor DT, Schmid-Schönbein GW. Plasma hydrogen peroxide production in hypertensives and normotensive subjects at genetic risk of hypertension. $J$ Hypertens 1998; 16: 291-303.

150 Wang D, Strandgaard S, Iversen J, Wilcox CS. Asymmetric dimethylarginine, oxidative stress, and vascular nitric oxide synthase in essential hypertension. Am J Physiol Regul Integr Comp Physiol 2009; 296: R195-R200.

151 Van der Zwan LP, Scheffer PG, Dekker JM, Stehouwer CD, Heine RJ, Teerlink T. Hyperglycemia and oxidative stress strengthen the association between myeloperoxidase and blood pressure. Hypertension 2010; 55: 1366-1372.

152 Fortuño A, Bidegain J, Baltanás A, Moreno MU, Montero L, Landecho MF, Beloqui O, Díez J, Zalba G. Is leptin involved in phagocytic NADPH oxidase overactivity in obesity? Potential clinical implications. J Hypertens 2010; Jun: 23.

153 Touyz RM, Schiffrin EL. Increased generation of superoxide by angiotensin II in smooth muscle cells from resistance arteries of hypertensive patients: role of phospholipase D-dependent $\mathrm{NAD}(\mathrm{P}) \mathrm{H}$ oxidase-sensitive pathways. J Hypertens 2001; 19: 1245-1254

154 Touyz RM, Yao G, Quinn MT, Pagano PJ, Schiffrin EL. p47phox associates with the cytoskeleton through cortactin in human vascular smooth muscle cells: role in $\mathrm{NAD}(\mathrm{P}) \mathrm{H}$ oxidase regulation by angiotensin II. Arterioscler Thromb Vasc Biol 2005; 25: 512-518.

155 Xaplanteris P, Vlachopoulos C, Baou K, Vassiliadou C, Dima I, loakeimidis N, Stefanadis C. The effect of p22(phox) -930A/G, A640G and C242T polymorphisms of NADPH oxidase on peripheral and central pressures in healthy, normotensive individuals. Hypertens Res 2010; May: 27.

156 Zalba G, San Jose G, Moreno MU, Fortuno A, Diez J. NAD(P)H oxidase-mediated oxidative stress: genetic studies of the p22(phox) gene in hypertension. Antioxid Redox Signal 2005; 7: 1327-1336.

157 Pacher P, Nivorozhkin A, Szabó C. Therapeutic effects of xanthine oxidase inhibitors: renaissance half a century after the discovery of allopurinol. Pharmacol Rev 2006; 58: 87-114

158 Simic DV, Mimic-Oka J, Pljesa-Ercegovac M, Savic-Radojevic A, Opacic M, Matic D, Ivanovic B, Simic T. Byproducts of oxidative protein damage and antioxidant enzyme activities in plasma of patients with different degrees of essential hypertension. J Hum Hypertens 2006; 20: 149-155.

159 Caner M, Karter Y, Uzun H, Curgunlu A, Vehid S, Balci H, Yucel R, Güner I, Kutlu A Yaldiran A, Oztürk E. Oxidative stress in human sustained and white coat hypertension. Int J Clin Pract 2006; 60: 1565-1571.

160 Mullan BA, Young IS, Fee H, McCance DR. Ascorbic acid reduces blood pressure and arterial stiffness in type 2 diabetes. Hypertension 2002; 40: 804-809.

161 Zureik M, Galan P, Bertrais S, Mennen L, Czernichow S, Blacher J, Ducimetière P, Hercberg S. Effects of long-term daily low-dose supplementation with antioxidant vitamins and minerals on structure and function of large arteries. Arterioscler Thromb Vasc Biol 2004; 24: 1485-1491.

162 Chen J, He J, Hamm L, Batuman V, Whelton PK. Serum antioxidant vitamins and blood pressure in the United States population. Hypertension 2002; 40: 810-816.

163 Hasnain BI, Mooradian AD. Recent trials of antioxidant therapy: what should we be telling our patients? Cleve Clin J Med 2004; 71: 327-334.

164 Jialal I, Devaraj S. Antioxidants and atherosclerosis: don't throw out the baby with the bath water. Circulation 2003; 107: 926-928.

165 Bosch J, Lonn E, Pogue J, Arnold JM, Dagenais GR, Yusuf S. Long-term effects of ramipril on cardiovascular events, and on diabetes: results of the HOPE study extension. HOPE/HOPE-TOO Study Investigators. Circulation 2005; 112: 1339-1346.

166 Kelly RP, Poo Yeo K, Isaac HB, Lee CY, Huang SH, Teng L, Halliwell B, Wise SD. Lack of effect of acute oral ingestion of vitamin $C$ on oxidative stress, arterial stiffness or blood pressure in healthy subjects. Free Radic Res 2008; 42: 514-522.

167 Mishra GD, Malik NS, Paul AA, Wadsworth ME, Bolton-Smith C. Childhood and adult dietary vitamin $\mathrm{E}$ intake and cardiovascular risk factors in mid-life in the 1946 British birth cohort. Eur J Clin Nutr 2003; 57: 1418-1425.

168 Poston L, Raijmakers M, Kelly F. Vitamin E in preeclampsia. Ann N Y Acad Sci 2004; 1031: 242-248.

169 Houston MC. Nutrition and nutraceutical supplements in the treatment of hypertension. Expert Rev Cardiovasc Ther 2010; 8: 821-833.

170 Widder JD, Guzik TJ, Mueller CF, Clempus RE, Schmidt HH, Dikalov SI, Griendling KK, Jones DP, Harrison DG. Role of the multidrug resistance protein-1 in hypertension and vascular dysfunction caused by angiotensin II. Arterioscler Thromb Vasc Biol 2007; 27: 762-768.

171 Cave A. Selective targeting of NAD(P)H oxidase for cardiovascular protection. Curr Opin Pharmacol 2009; 9: 208-213.

172 Fang J, Seki T, Maeda H. Therapeutic strategies by modulating oxygen stress in cancer and inflammation. Adv Drug Deliv Rev 2009; 61: 290-302.

173 Dulak J, Zagorska A, Wegiel B, Loboda A, Jozkowicz A. New strategies for cardiovascular gene therapy: regulatable pre-emptive expression of pro-angiogenic and antioxidant genes. Cell Biochem Biophys 2006; 44: 31-42.

174 Rey FE, Cifuentes ME, Kiarash A, Quinn MT, Pagano PJ. Novel competitive inhibitor of $\mathrm{NAD}(\mathrm{P}) \mathrm{H}$ oxidase assembly attenuates vascular $\mathrm{O}(2)(-)$ and systolic blood pressure in mice. Circ Res 2001; 89: 408-414.

175 Weseler AR, Bast A. Oxidative stress and vascular function: implications for pharmacologic treatments. Curr Hypertens Rep 2010; 12: 154-161.

176 Vendrov AE, Madamanchi NR, Liu XL, Molnar KC, Runge M, Szyndralewiez C, Page P, Runge MS. NADPH oxidases regulate CD44 and hyaluronic acid expression in thrombintreated vascular smooth muscle cells and in atherosclerosis. J Biol Chem 2010; 285: 26545-26557.

177 Gupte SA. Glucose-6-phosphate dehydrogenase: a novel therapeutic target in cardiovascular diseases. Curr Opin Investig Drugs 2008; 9: 993-1000.

178 Ferri C, Grassi D. Antioxidants and beneficial microvascular effects: is this the remedy? Hypertension 2010; 55: 1310-1311.

179 Rezzani R, Porteri E, De Ciuceis C, Bonomini F, Rodella LF, Paiardi S, Boari GE, Platto C, Pilu A, Avanzi D, Rizzoni D, Agabiti Rosei E. Effects of melatonin and pycnogenol on small artery structure and function in spontaneously hypertensive rats. Hypertension 2010; 55: 1373-1380.

180 Chen S, Ge Y, Si J, Rifai A, Dworkin LD, Gong R. Candesartan suppresses chronic renal inflammation by a novel antioxidant action independent of AT1R blockade. Kidney Int 2008; 74: 1128-1138.

181 Oliveira PJ, Goncalves L, Monteiro P, Providencia LA, Moreno AJ. Are the antioxidant properties of carvedilol important for the protection of cardiac mitochondria? Curr Vasc Pharmacol 2005; 3: 147-158.

182 Cifuentes ME, Pagano PJ. Targeting reactive oxygen species in hypertension. Curr Opin Nephrol Hypertens 2006; 15: 179-186.

183 Berk BC. Novel approaches to treat oxidative stress and cardiovascular diseases. Trans Am Clin Climatol Assoc 2007; 118: 209-214.

184 Sugiura T, Kondo T, Kureishi-Bando Y, Numaguchi Y, Yoshida O, Dohi Y, Kimura G, Ueda R, Rabelink TJ, Murohara T. Nifedipine improves endothelial function: role of endothelial progenitor cells. Hypertension 2008; 52: 491-498.

185 Roberts JM, Myatt L, Spong CY, Thom EA, Hauth JC, Leveno KJ, Pearson GD, Wapner RJ, Varner MW, Thorp Jr JM, Mercer BM, Peaceman AM, Ramin SM, Carpenter MW, Samuels P, Sciscione A, Harper M, Smith WJ, Saade G, Sorokin Y, Anderson GB. Vitamins $C$ and $E$ to prevent complications of pregnancy-associated hypertension. N Engl J Med 2010; 362: 1282-1291.

186 Tribble DL. Antioxidant consumption and risk of coronary heart disease: emphasis on vitamin $C$, vitamin $E$ and $\beta$-carotene. A statement for the healthcare professionals from the American Heart Association. Circulation 1999; 99: 591-595.

187 Hackam DG, Khan NA, Hemmelgarn BR, Rabkin SW, Touyz RM, Campbell NR, Padwal R, Campbell TS, Lindsay MP, Hill MD, Quinn RR, Mahon JL, Herman RJ, Schiffrin EL, Ruzicka M, Larochelle P, Feldman RD, Lebel M, Poirier L, Arnold JM, 
Moe GW, Howlett JG, Trudeau L, Bacon SL, Petrella RJ, Milot A, Stone JA, Drouin D, Boulanger JM, Sharma M, Hamet P, Fodor G, Dresser GK, Carruthers SG, Pylypchuk G, Burgess ED, Burns KD, Vallée M, Prasad GV, Gilbert RE, Leiter LA, Jones C, Ogilvie RI, Woo V, McFarlane PA, Hegele RA, Tobe SW. Canadian hypertension education program. The 2010 Canadian hypertension education program recommendations for the management of hypertension: part 2-therapy. Can J Cardiol 2010; 26: 249-258.
188 Agarwal D, Haque M, Sriramula S, Mariappan N, Pariaut R, Francis J. Role of proinflammatory cytokines and redox homeostasis in exercise-induced delayed progression of hypertension in spontaneously hypertensive rats. Hypertension 2009; 54: 1393-1400.

189 Bai Y, Sigala W, Adams GR, Vaziri ND. Effect of exercise on cardiac tissue oxidative and inflammatory mediators in chronic kidney disease. Am J Nephrol 2009; 29: 213-221. 